\title{
Aclimatização: estudo do reconhecimento de fala em usuários de próteses auditivas***
}

\author{
Acclimatization: speech recognition in hearing aid users
}

\author{
Letícia Pimenta Costa Spyer Prates* \\ Maria Cecília Martinelli Iório**
}

\begin{abstract}
* Fonoaudióloga. Mestre em Ciências pela Universidade Federal de São Paulo - Escola Paulista de Medicina. Fonoaudióloga do Hospital das Clínicas da Universidade Federal de Minas Gerais. Endereço para correspondência: Av. André Cavalcanti, 381, Apto. 204 - Belo Horizonte - MG - CEP 30430-110

(lepcosta@uai.com.br).

**Fonoaudióloga. Doutora em Distúrbios da Comunicação Humana pela Universidade Federal de São Paulo - Escola Paulista de Medicina. Professora Adjunta do Curso de Fonoaudiologia da Universidade Federal de São Paulo - Escola Paulista de Medicina.

***Trabalho Realizado na Universidade Federal de São Paulo Escola Paulista de Medicina.
\end{abstract}

Artigo de Pesquisa

Artigo Submetido a Avaliação por Pares

Conflito de Interesse: não

Recebido em 21.10.2005.

Revisado em 29.11.2005; 30.03.2006; 14.09.2006; 21.06.2006.

Aceito para Publicação em 21.06.2006.

\begin{abstract}
Background: acclimatization is the period that succeeds the fitting of hearing aids, when a progressive improvement of the hearing and speech recognition abilities is observed due to the new speech cues that are available to the hearing aid user. Aim: to verify acclimatization after the fitting of hearing aids through objective (speech tests) and subjective (Questionnaire) evaluations. Method: 16 hearing impaired individuals were evaluated on the first day of hearing aid fitting and were monthly reassessed for three months. In all three months the following speech tests were used: PISR - percentage index of speech recognition through monosyllabic words and SRT - speech recognition threshold through sentences, determining the speech/ noise ratio $(\mathrm{S} / \mathrm{N})$. The International Outcome Inventory of Hearing Aid (IOI-HA) was also applied in the first and third months after the hearing aids were fitted. Results: the comparison between the first day, first, second and third months after the hearing aids were fitted revealed a statistically significant improvement $(\mathrm{p}<0.001)$ between the results, not only for the PISR but also for the $\mathrm{S} / \mathrm{N}$ ratio. No statistically significant difference was found for the results obtained through the questionnaire applied in the first and third months. Conclusion: the objective evaluation, using speech recognition tests, presents better results in the months following the hearing aids fitting indicating a progressive improvement in the speech abilities from the first month onwards. The subjective evaluation does not reveal an improvement when comparing the first and third moths after the hearing aids were fitted.
\end{abstract}

Key Words: Hearing Aid; Acclimatization; Audiometry; Speech; Questionnaires; Hearing Loss

\section{Resumo}

Tema: a aclimatização refere-se ao período que sucede a adaptação dos amplificadores sonoros, quando ocorre uma melhora progressiva das habilidades auditivas e de reconhecimento de fala decorrente das novas pistas de fala disponíveis ao usuário da amplificação. Objetivo: verificar a aclimatização após adaptação de aparelhos de amplificação sonora individual (AASI) por meio de avaliações objetivas (testes de fala) e subjetivas (Questionário). Método: foram avaliados 16 deficientes auditivos no primeiro dia de adaptação de AASI e reavaliados mensalmente até o terceiro mês. Em todos os meses foram realizados os testes de fala Índice Percentual de Reconhecimento de Fala (IPRF), por meio de monossílabos, e Limiar de Reconhecimento de Sentenças no Ruído (LRSR), por meio de sentenças, determinando assim a relação sinal/ruído (S/R). Também foi aplicado o Questionário Internacional de Avaliação de Aparelhos de Amplificação Sonora Individual (QI - AASI) após um mês e três meses de adaptação das próteses auditivas. Resultado: a comparação realizada entre o primeiro dia, primeiro, segundo e terceiro meses de adaptação das próteses auditivas mostrou uma melhora estatisticamente significante $(\mathrm{p}<0,001)$ entre os resultados obtidos ao longo dos meses, tanto no IPRF, quanto na relação S/R. Não houve diferença estatisticamente significante nos resultados obtidos no questionário aplicado no primeiro e terceiro mês. Conclusão: a avaliação objetiva, por meio de tarefas de reconhecimento de fala, indica melhores resultados nos meses subseqüentes à adaptação das próteses auditivas evidenciando melhora progressiva das habilidades de fala a partir do primeiro mês de adaptação. A avaliação subjetiva não revela melhora entre o primeiro e o terceiro mês após a adaptação das próteses auditivas.

Palavras-Chave: Auxiliares de Audição; Aclimatização; Audiometria da Fala; Questionários; Perda Auditiva.

Referenciar este material como:

1 PRATES, L. P. C. S.; IÓRIO, M. C. M. Acclimatization: speech recognition in hearing aid users (original title: Aclimatização: estudo do reconhecimento de fala em $\sum 3$ usuários de próteses auditivas). Pró-Fono Revista de Atualização Científica, Barueri (SP), v. 18, n. 3, p.259-266, set.-dez. 2006. 


\section{Introduction}

The reduction of the indices of speech recognition, which is typical of bilateral hearing loss patients, results from the hearing privation throughout the years of deficiency. While these effects which result from hearing privation were being described in mid-80's, concomitantly there appeared studies showing a progressive improvement in the hearing abilities after a period of sound amplification use. Thus, they observed a hearing recovery in new users of hearing aids, in which the situation of hearing privation was interrupted with a significant improvement in the speech abilities after a certain period of amplification use. This phenomenon was called acclimatization (Almeida 2003).

In an attempt to explain the perceptual modifications that occur in users of hearing aids, Plilibert, Collet, Vesson, Veuillet (2002) hypothesized that the hearing rehabilitation in adults with neurosensorial hearing loss involves the functional plasticity. According to the authors, the central nervous system can reorgnize itself according to environmental changes. In their studies it was observed that when compared to non-users, hearing aids users presented a better performance in speech discrimination tasks and and intensity sensation, and this improvement was attributed to the functional plasticity.

The acclimatization, therefore, is related to the period that follows the adaptation of the sound amplifiers when a progressive improvement of the auditive abilities and of speech recognition, which result from the new traces of speech available to the amplifier user (Munro, Lutman, 2003). According to Almeida (2003), the use of sound amplification can improve speech recognition over time after a period of 6 to 12 weeks of sound amplification use.

As the success in the adaptation of hearing aids involves multiple facets, we cannot restrict the benefits of the acclimatization only to the improvement in speech recognition, but also focus on the aspects that involve all the communication of the user and and his degree of satisfaction as to his new condition as a user (Humes, Wilson et al, 2002).

The main complaint of the hearing impaired patient is related to the difficulty with oral communication, and this complaint is so persistent in new users of hearing aids that even after amplification, they present difficulties with sound recognition. Thus, the acclimatization is of key importance to the speech and hearing specialist as well as to his client in the process of adaptation of hearing devices. With the aim of not disregarding the importance of all the aspects that involve the process of hearing aids selection, as well as its electroacoustic characteristics and the skill of the professional in meeting the needs of the hearing impaired patient, the Acclimatization, as a natural phenomenon and inherent to this process, is quintessential to a good adaptation, considering use, benefit and user's satisfaction (Bucuvic, Iório, 2004).

That explains the value of all researches that help verify, validate and estimate how, when and why the acclimatization occurs. Considering the existence of a necessary period of use of sound amplification to re-establish the speech abilities obtained with the amplification, further studies are felt necessary for the accompaniment of the development of the hearing function in the new user of electronic sound amplification devices in order to verify how and when the sound acclimatization occurs, considering the speech abilities, use, benefit and user's satisfaction. Thus, the aim of the present study was to follow up the first 3 months of adaptation of hearing aids in new users, and to verify the acclimatization by means of objective and subjective evaluations.

\section{Method}

This study was carried out at the Integrated Nucleus of Assistance, Research and Teaching in Hearing (NIAPEA) at the University of São Paulo - Paulista Medical School, after due approval of the Committee of Ethics in Research of the aforementioned institution, under the protocol no. 0231/04. All the individuals of the sample signed a written informed consent to take part in the study voluntarily.

The elegibility criteria for selection of patients in this study were:

1. To be over 18 years of age;

2. To have symmetrical neurosensorial hearing loss, from slight to moderately severe degrees (i.e. average of the hearing threshold of up to $70 \mathrm{~dB}$ NA at the frequencies of $500,1,000,2,000 \mathrm{~Hz}$ );

3 . To have lost the hearing in the post-lingual period;

4. To be new users of hearing aids (HA), without previous experience, and with indication of bilateral adaptation;

5. HA acquired at the São Paulo Hospital through the program of Adaptation of Hearing Devices, of 
the Federal Government (APAC Auditiva - Decree no. 432-00);

6. Absence of any kind of perceptible cognitive or speech alterations.

Thus, 16 hearing impaired patients took part in this study, 8 of whom were women and 8 men, with ages ranging from 31 to 69, with an average of 52 years of age. As concerns the degree of hearing loss, 2 were slight, 2 moderate and 12 moderately severe. All the individuals adapted the same model and type of HA bilaterally, and these devices were digital, nonlinear, regulated according to the audiometry testing conducted previously and the NAL-NL rules for adaptation of hearing devices.

All the individuals were evaluated on the first day of adaptation of the hearing devices and reevaluated monthly until the third month.The evaluation consisted of the application of the following speech tests: Percentual Index of Speech Recognition (PISR) and Sentences Recognition Threshold (SRT) in noise. They also had to answer the International Outcome Inventory for Hearing Aids (IOI-HA) in the first and third months after the adaptation.

Research of the percentual index of speech recognition (PISR)

The percentual index of speech recognition in noise was carried out with the application of a list of 25 monosyllabic words devised by Pen, Mangabeira-Albernaz (1975) and recorded on a CD (Evaluation of Hearing Processing, CD-1, track 2, in Pereira, Schochat, 1997).

The words were presented in silence, at a fixed and comfortable level of intensity to the hearer, ranging from 65 to $75 \mathrm{~dB}(\mathrm{~A})$. The patient was instructed to repeat the words that he/she heard. The mistakes made by the patient were taken note of and a percentage of the words repeated correctly was established.

Research of the sentences recognition threshold (SRT) in noise and speech-noise ratio (S/N)

The evaluation of the threshold of speech recognition was carried out with the application of the Sentences Test in Portuguese (Costa, 1998). The speech material was presented in noise, using the list of sentences in the presence of competitive noise with the aim of establishing a speech-noise ratio $(\mathrm{S} / \mathrm{N})$.
Before the conduction of the test the patient was trained in silence as well as in noise, using the initial sentences on list $1 \mathrm{~A}$ at the same intensity as in the test to guarantee comprehension in the required task.

The procedure used for the application of the test was the "adaptative sequential strategy or ascending-descending" as suggested by the author of the test. Thus was determined the Sentences Recognition Threshold in Noise, that is, the necessary level for an individual to identify correctly about $50 \%$ of speech stimuli presented in the presence of ipsilateral competitive noise.

According to the adopted strategy, the application of the test consisted of the presentation of a speech stimulus at a certain intensity. When the response was correct, the intensity of the presentation of the following stimulus was reduced. When the response was incorrect, the intensity of the presentation of the following stimulus was increased. Intervals of 4 $\mathrm{dB}$ were used until the first change in the type of response, and later, the intervals of the presentation of stimuli were $2 \mathrm{~dB}$ between themselves to the end of the list.

A response was only considered incorrect when the individual repeated, without any error or omission, all the sentence presented.

In order to determine the SRT and, consequently, the $\mathrm{S} / \mathrm{N}$ ratio, the first sentence of each list was presented at an intensity of $65 \mathrm{~dB}(\mathrm{~A})$, since all the individuals of the sample who used hearing devices had hearing thresholds enough to perceive the speech stimulus at that intensity. The competitive noise was also presented at a fixed intensity of $65 \mathrm{~dB}(\mathrm{~A})$, so that the test started with a speech-noise ratio $(\mathrm{S} / \mathrm{N})$ of $0 \mathrm{~dB}$.

The levels of presentation of each sentence were taken note of during the evaluation at a specific protocol. The average of those values was calculated based on the levels of presentation of each sentence in which the first change of response occurred, to the level of presentation of the last sentence on the list, thus determining the thershold of sentence recognition.

For the calculation of the S/N ratio, the SRT of the intensity of noise presented was subtracted, which in this case was $65 \mathrm{~dB}$, bearing in mind that the $\mathrm{S} / \mathrm{N}$ ratio corresponds to the difference in $\mathrm{dB}$ between the value of the SRT (average of intensities of speech presentations in the presence of noise) and the value of the competitive noise utilized. 
Conditions of application of speech tests

The procedures of this research were carried out in a room of the NIAPEA, with acoustic treatment.

For the presentation of speech samples we used a Toshiba model 4147 portable compact disc player, attached to the hardware of the Madsen Electronics Aurical system (Aurical Audio Diagnostic Fitting System), which was attached to a Pentium processor.

The platform of the Aurical hardware as well as its software and accessories constitute the whole Aurical system, with all the necessary requirements to conduct a liminal tonal audiometry testing, speech tests by means of phones and free field, and even measurements of electroacoustic characteristics of hearing aids, as well as connections of different types of transductors and other accessories.

In order for us to apply the proposed tests by means of this system, we entered the program manager NOAH, and then selected the Aurical audiometer and made the adjustments for the necessary output type according to the applied test, that is, output for two independent channels in free field in speech tests, with a possibility of ranging the stimuli 2 by $2 \mathrm{~dB}$.

The speech tasks were carried out in free field thus evaluating the binaural hearing of a bilaterally prosthetized individual, positioned opposite the loudspeaker, at a distance of one meter to $0^{\circ}$ azimuth.

Every speech sample as well as the noise used were calibrated in $\mathrm{dB}(\mathrm{A})$ by using a Radio Shack, model 33-2055 measurer of sound pressure level. As suggested by Costa (1998), the sound pressure level was measured, in which both the speech as well as the noise were reaching the tested individual's ear. The measurement equipment was placed in a middle position between the two ears, at a distance of one meter from the loudspeaker. For the measurements we used the A scale, with quick answers, for this was the most appropriate one for measuring continous sounds and for determining the extreme values of intermittent noises.

Both the sound pressure levels of the noise as well as the speech were verified. In order to obtain the noise level in free field, the intensity between the modulations was measured, for it was a continuous sound that presents a small modulation of $1 \mathrm{~dB}$. As in speech there was a difference of 30 $\mathrm{dB}$ between the more intense sound and the less intense one, it was necessary to come up with an average reference value, which was obtained through the calculation of the avarage values of the peaks of highest amplitude of each sentence on the list.

After that, a volume unit (V.U.) was adjusted to zero position during the presentation of a pure tone to $1.000 \mathrm{~Hz}$ recorded at the beginning of the CDs, in order to guarantee the recordability of the conditions of presentantion.

International outcome inventory for hearing aids (IOI-HA)

The filling in of the International Outcome Inventory for Hearing Aids - translated into Brazilian Portuguese by Bevilacqua, Henriques et al in Cox et al, 2002 - was conducted with direct guidance of the researcher together with the individual, thus guaranteeing the comprehension of questions and answers. The questionnaire, which was composed of 7 questions, evaluated in a subjetive manner the result of the adaptation of the electronic amplification sound device based on the following aspects: 1Use; 2- Benefit; 3-Residual limitation of activities; 4Satisfaction; 5-Residual restriction of participation; 6- Impact on others; 7-Quality of life.

The questionnaire listed and option of 5 answers graded from left to right in such a way that the first option referred to a worse performance, whose score was 1 ; the last option indicated a better performance, whose score was 5 . The patient was guided to opt for only one answer, the one that most characterized the result of the adaptation of his/her electronic device.

The analysis of the IOI-HA questionnaire was done considering the punctuation of each question and the total punctuation obtained in the first 7 questions. As refers the punctuation obtained in each analysis, it is important to point out that the items 1 to 7 of the questionnaire have a minimal punctuation of 1 and a maximum of 5 . The total punctuation involves the answer of the first 7 items which make up a minimal punctuation of 7 and a maximum of 35 . The highest punctuation indicates better results in relation to the adaptation of the hearing aid.

Routine of evaluation

\section{Day one}

The first day of evaluation of the patient was carried out in the same session as the adaptation of the hearing aids. After the placement of the hearing aids and selection of their electroacoustic characteristics, a research on the functional gain in free field was carried out in order to certify the minimal hearing that the individual using sound amplification had. 
Afterwards, the PISR test was applied and so was the SRT test. On this first day of evaluation, the list 2B of the test SRT was used. The list of the PISR was the same used during all the follow-ups of the evaluation.

Month 1

About 30 days after the adaptation of the hearing aids, the patients returned to undergo the speech recognition test once again as well as the application of the IOI-HA.

Month 2

About 60 days after the adaptation, the patients returned to undergo the speech tests once more. At this moment, the list of sentences $4 \mathrm{~B}$ in the research of the SRT was applied.

Month 3

After 90 days of the adaptation of the hearing aids, the whole procedure of evaluation of speech tasks and the application of the IOI-HA was repeated.

In this last follow-up we utilized the sentence list 2B in the research of the SRT, the same used on the first day of adaptation, in order to compare the evolution of the patient in the sentence recognition task under the same conditions, and by means of the same speech material applied initially. It is important to state that the 3 sentence lists used in this study are similar considering the degree of difficulty and the number of phonemes in the Portuguese language, thus guaranteeing homogeneity in the evaluation as well as reliability in the comparisons made (Costa, 1998). We opted not to repeat the same sentences throughout the 3 months because of the facility it would offer and the redundancy of the contents, which would contribute to the memorization of the sentences by the patient.
For the research of the PISR the speech sample remained unaltered, for we considered difficult for the patient the memorization of the word list throughout the 3 months, thus maintaining a material worthy of comparison. It is important to point out that the whole speech evaluation was carried out maintaining the same conditions of test application, which were already described above.

\section{Statistical treatment}

As concerns the results obtained in the speech tasks, they were analyzed and compared statistically, by using the Friedman test (comparison of three by three variables) and the Wilcoxon test (comparison of two by two variables), establishing a significance of $5 \%$. The analysis of the questionanaire was carried out by using the MannWhitney technique, with a significance of 5\%.

\section{Results}

Ther results of the PISR and of the SRT $(\mathrm{S} / \mathrm{N})$, considering the average values, median, standard deviation and the $p$ value obtained by the Friedman test, with a comparison between the first day and the subsequent months are as follows. The application of this test allows us to compare the 4 variables simultaneously. (see Table 1 ).

In order to verify whether a difference in the results and/or compare the months two by two, the Wilcoxon test was applied. In this manner, the table 2 presents the p values obtained in the comparisons made between the first day and the subsequent months, two by two.

The answers obtained in the IOI-HA were compared between the first and the third months. The table 3 shows the values of the average, median, standard deviation, size and p value of the answers obtained in each question and the total punctuation obtained in the questionnaire. This comparison was made by using the Wilcoxon test.

TABLE 1. Values of the average, standard deviation and P value of the PISR and SRT $(\mathrm{S} / \mathrm{N})$ on the first day, first, second and third months of adaptation of the ha.

\begin{tabular}{|c|c|c|c|c|c|c|c|c|}
\hline & \multicolumn{4}{|c|}{ PISR } & \multicolumn{4}{|c|}{$\mathrm{S} / \mathrm{N}$} \\
\hline & $1^{\text {st }}$ Day & $\begin{array}{c}1^{\text {st }} \\
\text { Month } \\
\end{array}$ & $\begin{array}{c}2^{\text {nd }} \\
\text { Month } \\
\end{array}$ & $\begin{array}{c}3^{\text {rd }} \\
\text { Month } \\
\end{array}$ & $1^{\text {st }}$ Day & $\begin{array}{c}1^{\text {st }} \\
\text { Month } \\
\end{array}$ & $\begin{array}{c}2^{\text {nd }} \\
\text { Month } \\
\end{array}$ & $\begin{array}{c}3^{\text {rd }} \\
\text { Month }\end{array}$ \\
\hline Average & 58.50 & 59.50 & 70.25 & 72.00 & 1.92 & 2.04 & -1.23 & -3.54 \\
\hline Median & 58 & 56 & 68 & 68 & 2.5 & 2.4 & -2.4 & -4.5 \\
\hline $\begin{array}{l}\text { Standard } \\
\text { deviation }\end{array}$ & 16.71 & 15.52 & 12.30 & 11.96 & 4.89 & 4.90 & 4.50 & 3.47 \\
\hline p value & \multicolumn{4}{|c|}{$<.001^{*}$} & \multicolumn{4}{|c|}{$<.001^{*}$} \\
\hline
\end{tabular}

Abbreviations: S/N:speech-noise ratio; *indicative of a statistically significant value. $\mathrm{P}$ value $<0.05 ; \mathrm{N}=16$. 
TABLE 2. P values of the PISR and SRT (S/N) obtained in the comparison two by two between the results obtained on the first day, first, second and third months of adaptation of the HA.

\begin{tabular}{clccc}
\hline & & $\mathbf{1}^{\text {st }}$ Day & $\mathbf{1}^{\text {st }}$ Month & $\mathbf{2}^{\text {nd }}$ Month \\
\hline \multirow{3}{*}{ PISR } & $\mathbf{1}^{\text {st }}$ Month & 0.590 & & \\
& $\mathbf{2}^{\text {nd }}$ Month & $0.002^{*}$ & $0.001^{*}$ & \\
& $\mathbf{3}^{\text {rd }}$ Month & $0.001^{*}$ & $0.001^{*}$ & 0.112 \\
& 1st Month & 0.865 & & \\
S/N & $\mathbf{2}^{\text {nd }}$ Month & $0.001^{*}$ & $<0.001^{*}$ & \\
& $\mathbf{3}^{\text {rd }}$ Month & $0.001^{*}$ & $0.001^{*}$ & $0.004^{*}$ \\
\hline
\end{tabular}

Abbreviations:S/N: speech-noise ratio; * indicative of a statistically significant value. $\mathrm{P}$-value $<0.05 ; \mathrm{N}=16$

TABLE 3. Values of the average, median, standard deviation, size and $P$ value obtained with the analysis of the IOI-HA, applied in the first and third month of adaptation of the ha.

\begin{tabular}{cccccc}
\hline Questionnaire & Average & Median & $\begin{array}{c}\text { Standard } \\
\text { Deviation }\end{array}$ & P value \\
\hline \multirow{2}{*}{ Q1 } & $\mathbf{1}^{\text {st }}$ month & 4.75 & 5 & 0.45 & 0.655 \\
& 3 $^{\text {rd }}$ month & 4.81 & 5 & 0.40 & \\
Q2 & $\mathbf{1}^{\text {st }}$ month & 4.25 & 4 & 0.45 & 0.257 \\
& 3 $^{\text {rd }}$ month & 4.44 & 4 & 0.51 & \\
Q3 & $\mathbf{1}^{\text {st }}$ month & 4.06 & 4 & 0.85 & 0.248 \\
& $3^{\text {rd }}$ month & 4.31 & 4 & 0.70 & \\
Q4 & $\mathbf{1}^{\text {st }}$ month & 4.50 & 5 & 0.63 & 0.279 \\
& $3^{\text {rd }}$ month & 4.75 & 5 & 0.58 & \\
Q5 & $\mathbf{1}^{\text {st }}$ month & 4.81 & 5 & 0.40 & 0.564 \\
& $3^{\text {rd }}$ month & 4.75 & 5 & 0.45 & \\
Q6 & $\mathbf{1}^{\text {st }}$ month & 4.63 & 5 & 0.62 & 0.480 \\
& $3^{\text {rd }}$ month & 4.75 & 5 & 0.58 & \\
Q7 & $\mathbf{1}^{\text {st }}$ month & 4.38 & 5 & 0.81 & 0.603 \\
& $3^{\text {rd }}$ month & 4.25 & 5 & 1.06 & \\
QT & $\mathbf{1}^{\text {st }}$ month & 31.38 & 32 & 2.33 & 0.178 \\
\hline
\end{tabular}

Abbreviations:Q: question; QT: sum of all the questions; N=16.

\section{Discussion}

All the 16 individuals were evaluated on the first day of adaptation of his/her hearing aids and re-evaluated monthly until the third month. The objective evaluation consisted of the application of speech tests, such as the Percentual Index of Speech Recognition (PISR) and the Sentences Recognition Threshold (SRT) in noise.

The comparison made between the first day, second and third months of adaptation of hearing aids showed a statistically significant improvement ( $p<0.001$ ) between the results obtained throughout the months for the PISR as well as the $\mathrm{S} / \mathrm{N}$ ratio, thus evidencing acclimatization (Table 1).

Several studies were done with the aim of evaluating acclimatization after a certain period of use of hearing aids (Humes et al, 2002; Philibert et al, 2002; Kuk, Poos et al, 2003; Munro e Lutman, 2003, Humes e Wilson, 2003; Flynn, Davis e Pogash, 2004). All of them pointed to a perceptible improvement in the speech abilities or a subjective benefit after continuous use of sound amplification. However, the authors reported different 
experiences as to the interval of the evaluation in which the greater significant change and the stability of such a change can be noticed.

In table 2 we analyzed when the improvement in speech recognition occurred. In this manner, we compared the results obtained between the months and verified that there was a statistically significant difference for the PISR as well as the SRT, when the results obtained in the first/third months were compared and between the first month and the second/third months. This means that there were evidences of improvement in speech recognition after 30 days of adaptation of hearing aids, and this improvement was optimized up to 60 days of sound amplification use.

When we analyzed table 2, there was no statistically significant difference for the PISR nor the SRT between the first day and the first 30 days of adaptation, thus indicating that Acclimatization only starts to occur after thr first month of sound amplification use.

As for the SRT test, we observed a continous improvement in the $\mathrm{S} / \mathrm{N}$ ratio up to 90 days after the adaptation of hearing aids, evidenced by statistically significant differences between the subsequent months. This indicates that the ability of speech recognition in the presence of noise improves until the third month, and we cannot state whether after the 90 days of adaptation the individual continues developing his/her process of acclimatization, or whether he/she reaches the peak of improvement in this ability.

Humes et al (2002) followed the first year of hearing aids use in 134 elderly persons by means of speech tasks and questionnaires. These people were evaluated after the first month, six months and 1 year of adaptation. 49 of those individuals continued being followed up to the second year of sound amplification use. Significant changes between the users were observed throughout the months. However, the results with greater significant change occurred between the first and sixth month when compared with the results obtained with 1 year of use. As for the patients followed up after the second year, minimal changes were observed.

As a way of verifying the acclimatization by means of subjective measurement considering use, benefit and user's satisfaction, we applied the IOIHA after the first and third months of adaptation of hearing aids. There was no statistically significant change between the results obtained in the IOI-HA, not evidencing any improvement between the first and third month of adaptation. Contrary to what was verified in the present study,
Humes et al (2002) reported that the evidences of acclimatization were showed in a significant way, mainly by means of subjective measurements (selfevaluating questionnaires).

However, although the present study did not show any signs of acclimatization by means of the applied questionnaire, we could observe a positive result to hearing adaptation, evidenced by the high punctuation obtained per question (maximum punctuation possible 5) and in the total evaluation of the questionnaire maximum punctuation possible 35). In this manner, there had been no evident dissatisfaction as to the questions listed on the questionnaire since the first month of adaptation, with a confirmation of this impression in the evaluation carried out after the third month. However, in spite of the positive results obtained in the subjective evaluation, such satisfaction is a little suspicious to us, given the fact that this could reveal an attitude of humility and gratitude from our patients, who got hearing aids totally free of charge, and, consequently, did not feel they had the right to expressing any kind of dissatisfaction.

However, another study done by Bucuvic, Iório (2004) who evaluated, by means of an APHAB questionnaire, the subjective benefit of new users of hearing aids, which were also donated, after 2 and 3 months of use evidenced a significant improvement of hearing difficulties after 2 and 6 months of adaptation. The authors pointed out that regardless of the time of use of sound amplification, the hearing difficulties of users of hearing aids are greater than those of individuals with normal hearing.

Cox \& Alexander (2002) also verified a high punctuation for individuals evaluated in the IOIHA in his study, suggesting favorable atittudes in relation with the use of hearing aids. They commented on the likely sensibility of the questionnaire to detect individuals with negative experience in relation with hearing aids.

We applied the IOI-HA for it was a brief, encompassing questionnaire and accessible to the different cultural and social factors for use and for diverse comparisons (Cox et al, 2000) with a focus, as in this study, of comparing the lineal and nonlineal sound amplification. However, in spite of the self-explanatory aspect of the questionnaire, which was devised to be answered without any kind of additional help (Cox e Alexander, 2002), in this study it was applied by the researcher in charge in order to guarantee total comprehension of the questions and answers, for many users who were evaluated presented difficulties with reading and the interpretation of questions. 


\section{Conclusion}

The objective evaluation by means of tasks of speech recognition indicates better results in the subsequent months to the adaptation of hearing aids evidencing a progressive improvement of speech abilities from the first month of adaptation. The subjective evaluation did not evidence any improvement between the first and third months after the adaptation of hearing aids.

\section{References}

ALMEIDA, K. Avaliação dos resultados da intervenção. In: ALMEIDA, K.; IÓRIO, M. C. M. Próteses Auditivas: fundamentos teóricos e aplicações clínicas. 2. ed. São Paulo: Lovise, 2003. p. 357-379.

BUCUVIC, E. C.; IÓRIO, M. C. M. Benefício e dificuldades auditivas: um estudo em novos usuários de próteses auditivas após dois e seis meses de uso. Fono Atual, São Paulo, v. 29, n. 7, p. 19-29, 2004.

COSTA, M. J. Lista de sentenças em português: apresentação e estratégias de aplicação na audiologia. São Paulo: Pallotti, 1998.

COX, R. M.; HYDE, M.; GATEHOUSE, S.; NOBLE, W.; DILLON, H.; BENTLER, R.; STEPHENS, D.; ARLINGER, S.; BECK, L.; WILKERSON, D.; KRAMER, S.; KRICOS, P.; GAGNÉ, J. P.; BESS, F.; HALLBERG, L. Optimal outcome measures, research priorities, and international cooperation. Ear Hear., v. 21, n. 4, p. 106S-115S, 2000.

COX, R. M.; ALEXANDER, G. C. The international outcome inventory for hearing aids (IOI-HA): psychometric properties of the english version. Int. J. Audiol., v. 41, n. 1, p. 30-35, 2002.

COX, R. M.; STEPHENS, D.; KRAMER, S. E. Translations of the international outcome inventory for hearing aids (IOI - HA). Int J. Audiol., v. 41, n. 1, p. 3-26, 2002.

COX, R. M.; ALEXANDER, G. C.; BEYER, C. M. Norms for the international outcome inventory for hearing aids. J. Am. Ac. Audiol., v. 14, n. 8, p. 403-413, out. 2003.

FLYNN, M. C.; DAVIS, P. B.; POGASH, R. Multiplechannel non-linear power hearing instruments for children with severe hearing impairment: long term follow-up. Int. J. Audiol., v. 43, n. 8, p. 479-485, set. 2004.
We can conclude that acclimatization is progressive and results from use of acoustic traces provided by the use of hearing aids. In this manner, we can rely on the "effects of time" as an ally in the success of adaptation and acceptance of hearing aids by their users.
HUMES, L. E.; WILSON, D. L; BARLOW, N. H.; GARNER, C. Changes in hearing-aid benefit following 1 or 2 years of hearing-aids use by older adults. J. Speech Lang. Hear. Res., v. 45, n. 4, p. 772-782, ago. 2002.

HUMES, L. E.; WILSON, D. L. An examination of changes in hearing-aid performance and benefit in the early over a 3-year period of hearing-aid use. J. Speech Lang. Hear. Res., v. 46, n. 1, p. 137-145, fev. 2003.

KUK, F. K.; POTTS, L.; VALENT, M.; LEE, L.; PICIRRILLO, J. Evidence of acclimatization in persons with severe-to-profound hearing loss. J. Am. Acad. Audiol., v. 14, n. 2, p. 84-99, 2003.

MUNRO, K. J.; LUTMAN, M. E. The effect of speech presentation level on measurement of auditory acclimatization to amplified speech. J. Accoust. Soc. Am., v. 114, n. 1, p. 484-495, jul. 2003.

PEN, M.; MANGABEIRA-ALBENAZ, P. L. Desenvolvimento de teste para logoaudiometria discriminação vocal. In: CONGRESSO PANAMERICANO DE OTORRINOLARINGOLOGIA E BRONCOESOFAGIA. 1973, Lima. Anales... Lima (Peru): [s.n.]. 1973. p. 223-226.

PEREIRA L. D.; SCHOCHAT, E. Manual de avaliação do processamento auditivo central. São Paulo: Lovise, 1997.

PHILIBERT, P.; COLLET, L.; VESSON, J. F.; VEUILLET, E. Intensity-related performance are modified by longterm hearing aid use: a functional plasticity? Hear. Res., v. 165, n. 1 e n. 2, p. 142-151, 2002. 